Volume 6 Issue 4, December 2019

Nationally Accredited Journal,

Decree No. B/4130/E5/E5.2.1/2019

\title{
Juridical Review on Grants of Treasure Together Of Child Due Divorce In Religious/ Islamic Courts of Kendal
}

\author{
Bagus Malik Hakim¹, Akhmad Khisni ${ }^{2}$ and Munsharif Abdul Chalim ${ }^{3}$
}

\begin{abstract}
Divorce in the event, then the entire joint property, the property acquired during the marriage is divided into two parts, namely the upper half of the husband and half to the wife. Kendal Religious Court in deciding the division of joint property, there are in accordance with the provisions of Islamic Law Compilation, is half portion for half of the husband and wife to. But there is also, Kendal Religious Courts decide part of the joint property of the wife is greater, which is part of the joint property to the wife more than in the joint property of the husband. There is also, the Religious Courts Kendal cut off all joint property is granted (given) to his son.

The purpose of this research are: 1) To know and understand the implementation of joint property grants to children of divorce in the Religious Kendal. 2) To know and understand the considerations related decision Religious Court judges Kendal in community property donated to the children of divorce. 3) To know and understand the barriers and solutions implementation of joint property grants to children of divorce in the Religious Kendal. The data used in this study are primary data, secondary data and data that can support tertiary study, which was then analyzed by descriptive analytical method.

Kendal Religious Court Decision on the Implementation of the Joint Grant Treasure Kids Due To Divorce Court Kendal Religion is a decision that truly reflects the sense of justice, reflect expediency and legal certainty. Therefore, when the divorced husband and wife agreed to grant the joint property willed to his son, accompanied by a deed of peace. Therefore, the verdict ideal is when it contains elements of Gerechtigekeit (justice), Zweckmassigkeit (benefit), and Rechtssicherheit (rule of law) in proportion.

Keywords: Overview of Juridical; Grant; Treasure Together; Divorce.
\end{abstract}

\section{Introduction}

The Divorce may be done, but it should really in the truly emergency situation and forced situation. ${ }^{4}$ Divorce there must be reasons for divorce, either divorce filed by a husband against his wife or divorce filed by a wife against her husband.

Divorce in the event, then the entire joint property, the property acquired during the marriage is divided into two parts, namely the upper half of the husband and half to the wife. Because, according to the provisions of Article 35 of Law Republic of Indonesia No. 1 of 1974 About Marriage Article 35 Paragraph (1), that "Possessions acquired during the marriage becomes possessions together". And Elucidation of Article 35 Paragraph (1), that "if the marriage broke up, the joint property is governed by the law of each". ${ }^{5}$

The purpose of the "legal individual" is mentioned in Article 37 of the Company Law of the Republic of Indonesia Number 1 of 1974 About Marriage, that "The meaning of the law respectively mean religious law, customary law and other laws".

If people who are Muslims have certainly spoken law is Islamic law. In the Compilation of Islamic Law Article 88, that "In the event of a dispute between husband and wife

\footnotetext{
${ }^{1}$ Student Master of Notary, Sultan Agung Islamic University, Semarang, Email: bagusmalikhakim@gmail.com

${ }^{2}$ Lecturer, Faculty of Law, Sultan Agung Islamic University, Semarang, email khisni@unissula.ac.id

${ }^{3}$ Lecturer, Faculty of Law, Sultan Agung Islamic University, Semarang, email munsharif@unissula.ac.id

${ }^{4}$ Abdul Manan, 2001, Problematika perceraian Karena Zina Dalam Proses Penyelesaian Perkara Di lingkungan Peradilan Agama, Mimbar hukum, No. 52 Thn. XII, Jakarta: Al-Hikmah \& Ditbin bapera Islam, p. 7-8.

${ }^{5}$ Article 35 of Law No. 1 of 1974 About Marriage
} 
concerning joint property, dispute settlement was filed with the Court of Religion". Furthermore, in Article 97 explains that "divorced widow or widower each entitled to half of the community property along with no other in the marriage covenant". ${ }^{6}$

However, in practice, Kendal Religious Court ruling on the division of property together, there is in accordance with the provisions of Islamic Law Compilation, namely $1 / 2$ (half) part of the joint property of husband and $1 / 2$ (half) part of the joint property to his wife. But there is also, Kendal Religious Courts decide part of the joint property of the wife is greater, which is part of the joint property to the wife more than in the joint property of the husband. In other words, part of common property of husband less than the treasure together for the wife. There is also, the Religious Courts Kendal cut off all joint property is granted (given) to his son.

Thus, the decision of the Islamic Court Kendal deviate the provisions of the legislation in force in Indonesia. Namely, the ruling Islamic Court Kendal deviate the provisions of the Compilation of Islamic law and the provisions of the hadith of the Prophet Muhammad From 'Amr bin Shu'aib, from his father, from his grandfather, he said that there is a man came to the Prophet sallallaahu' alaihi wa sallam, then he said, "O Messenger of Allah, verily I have wealth and children. However, my parents are in need of my treasures. Then he answered: "You and your wealth belong to your parents. Surely your children is the best of both of yourselves. Eat of the results of operations of your children. "(HR. Abu Dawud).

And SWA Prophet once said to someone, "You and your wealth is your father." (Ash-Shafi'i and Abu Dawud).

An understanding of the Compilation of Islamic Law, in particular the law of the division of joint property due to divorce by Superior Court Judge Religion Kendal in its application is not absolute, but relatively accordance with the relative nature of the man himself and the relative nature of social development, or more specifically the influence of the life of Muslim community in Indonesia that influenced the development of Islamic law, especially the law of division of community property.

To answer the gap between solen sein division of property between joint law contained in the compilation of Islamic law with reality through the verdict courts that cause problems, it is important to do research to find answers to solve the problem by doing ijtihad. So the purpose of this study is the first, to know and understand the implementation of joint property grants to children of divorce in the Religious Kendal. Second, to know and understand the considerations related decision Religious Court judges Kendal in community property donated to the children of divorce. And third, to know and understand the barriers and solutions implementation of joint property grants to children of divorce in the Religious Kendal.

\section{Research Methods}

Research that I use is using normative juridical approach. The research location is in the Religious Court Kendal. Specifications research using descriptive analysis. ${ }^{7}$ The source of data is obtained from the primary law, secondary law, and tertiary legal materials. Technic of data analysis is the data obtained by examining data from primary legal materials and secondary law, then drawn a conclusion that the answer to the issue raised in this study, then collected and processed systematically in the form of information, then analyzed qualitatively to describe the results of the study as a step in answering the questions,

\footnotetext{
${ }^{6}$ Article 97 Compilation of Islamic Law

${ }^{7}$ Masri Singrimbun and Sofyan Efendi, 1995, Metode Penelitian Survai, Jakarta: LPJES,p. 10.
} 
Volume 6 Issue 4, December 2019

Nationally Accredited Journal,

Decree No. B/4130/E5/E5.2.1/2019

furthermore systematically drafted in the form of research. ${ }^{8}$

\section{Results and Discussion}

\subsection{Implementation Of Grants On Treasure Together Of Child Due Divorce In Religion/Islamic Court of Kendal}

Implementation grant joint property (Gono-gini) to children of divorce in the Religious Kendal is after the ruling Islamic Court Kendal regarding grants or provide joint property (Gono-gini) to the children of divorce and the child is still a minor or a minor child or the child has not reached the age of 21 years, the asset together (Gono-gini) donated or given to the child maintained or under supervision by one of the parents of the child as guarded or under supervision by the mother of the child or maintained or under supervision by the father of the child. Therefore, minors are not able or not able to maintain or or supervise or regulate the treasure.

However, if after the ruling Islamic Court Kendal regarding grants or provide joint property (Gono-gini) to the children of divorce and the child is an adult or a child has reached the age of 21 years, the asset together (Gono-gini) donated or are in given by parents to children is directly controlled by the child because the child is able or has been able to manage or supervise the treasure.

In other words, a child who is already an adult or child who has reached the age of 21 are already able to maintain or have been able to organize such property.

Furthermore, both parents (father and mother of the child) manage the process behind the name of the parents to the children who grant joint property (Gono-gini) has to be completed, so that the property becomes the property of the child in full.

\subsection{Considerations Related Judge Kendal Religious Court decision in granting treasure Together Children Due To Divorce}

2.2.1. After the authors examine and observe Kendal Religious Court Decision', No. 1451 / Pdt.G / 2016 / PA Kdl., Authors can discuss or analyze it as follows:

At first, the Plaintiff named SMT binti Stmn Defendant named MKW bin S is a legitimate couple. ${ }^{10}$ During the marriage Plaintiffs named SMT daughter named Stmn Defendant S MKW son has been blessed with a son named RS. During the marriage, Plaintiff named SMT binti Stmn Defendant named MKW bin S had granted a joint property (Gono-gini)in the form of a dwelling house building covering an area of 105.12 M2 which stands on land owned Smn bin Gm (grandmother of Defendant) Which covers 175.5 M2 located in the hamlet Bulugede Wetan RT. 008 RW. 003, Bulugede Village, District Patebon, Kendal recorded on letter $C$ Village Bulugede Persil 73 Klas IN

But then the Plaintiff named SMT bin Stmn and Defendants named MKW bin S Religion divorced by the Court's decision Kendal No. 1477 / Pdt.G / 2012 / PA Kdl. on Tuesday, October 16, 2012.Once the decision is final and binding (inkrahct van gewisjde), The Religious Courts Kendal publish Divorce Certificate No. 1976 / AC / 2012 / PA Kdl., Then from then husband named MKW bin S which is now referred to as the Defendant and his wife were called SMT bin Exp Plaintiff is now called officially divorced. Then, the Plaintiff

${ }^{8}$ Ronny Hanitijo Soemitro, 1998,Metodologi Penelitian Hukum dan Jurimetri, Jakarta : Ghalia Indonesia, p. 10.

${ }^{9}$ A copy of the Decision Kendal Religious Court, No. 1451 / Pdt.G / 2016 / PA Kdl

10 Name changed to protect confidentiality 
named SMT bin Exp filed joint property (Gono-gini) against Defendants named MKW bin S with the claim letter dated July 20, 2016 registered at the Registrar of Kendal Religious Court No. 1451 / Pdt.G / 2016 / PA Kdl. dated July 20, 2016 by postulating as mentioned above. Then, the named Plaintiffs and Defendants Stmn SMT daughter named MKW bin S has been reconciled through mediation by a mediator and at each session by the judges, but to no avail.

To claim Plaintiff that common property is determined given or donated to children Plaintiff by Defendants named RS, while the Defendant wants joint property is set given donated to children Defendant named RS with the proviso after the grandmother of Defendants named SMN Gm daughter died first. Therefore, the Judge argues that the Defendants did not mean it give or grant a joint property (Gono-gini) the child Plaintiff by Defendants named the hospital because all the people will not know when the grandmother of Defendants named SMN the Gm daughter died, including Plaintiff and Defendant did not know when the certainty of the Defendant's grandmother died.

Because, gifts or bequests from one person to another party qualifies as granting. Therefore, the grant can only be done by the owner of the property, voluntary, grant object obvious, and grantees are mukallaf or are under the guardianship of someone who is legally competent. ${ }^{11}$ Based on the word of the Prophet Muhammad (hadith narrated by Ibn Majah) which reads:

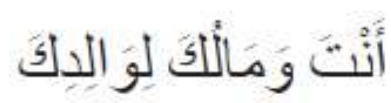

Meaning: "You and your treasures are the property of your parents".

And the jurisprudence of the Supreme Court decision No. 266 / K / AG / 2010 dated July $12,2010 .{ }^{12}$

Furthermore, Judge (Judges) establish joint property (Gono-gini) Plaintiff by the Defendant should be divided into two parts, for Plaintiff and to the Defendants. Then Judge (Judges) assign each section, the plaintiff is entitled to $1 / 2$ (half) part of the joint property, and the Defendant is entitled to $1 / 2$ (half) part of the joint property. And division of joint property in accordance with the provisions of Article 97 Compilation of Islamic Law, which is "divorced widow or widower each entitled to half of the community property along not otherwise stipulated in the marriage contract".

Treasure together (Gono-gini) that if it can not be divided by nature, then each in order to sell it by auction in public and leave the results to each entitled to receive, the Plaintiff and Defendant by comparison, as mentioned above, namely $1 / 2$ (half) for Plaintiffs and $1 / 2$ (half) for the Defendant.

Thus, we can conclude that although the father and mother of the child have agreed wanted to give or donate joint property to his son, but the father filed the terms of which are difficult to be implemented as requested by MKW bin $S$ as described above, the joint property can not be granted or given to children.

2.2.2. After the authors examine and observe Kendal Religious Court Decision ${ }^{13}$, No. 1279 / Pdt.G / 2016 / PA Kdl., Authors can discuss and analyze them as follows:

At first, the Plaintiff named Slt binti Kr Defendant named Spt bin Wky is a legitimate couple. During the marriage Plaintiffs named Slt daughter named Kr Defendant Wky Spt son has been blessed with two (2) children, each namedAT and $\mathrm{HTS}^{14}$ During the marriage, Plaintiff named SIt binti Kr Defendant called Spt bin Wky had granted a joint

\footnotetext{
11 Abdul Kadir Muhammad, 1988, Perkembangan Hukum Keluarga Di beberapa Negara Eropa, Bandung: Publisher Aditya Bakti.

12 The jurisprudence of the Supreme Court decision No. 266 / K / AG / 2010

${ }^{13} \mathrm{~A}$ copy of the Decision Kendal Religious Court, No. 1279 / Pdt.G / 2016 / PA Kdl

14 Name changed to protect confidentiality
} 
Volume 6 Issue 4, December 2019

Nationally Accredited Journal,

Decree No. B/4130/E5/E5.2.1/2019

property (Gono-gini).

But then Plaintiff named Slt binti Kr Defendant called Spt bin Wky has been divorced from the date of February 7, 2019 based on the Deed of Religious Court Kendal No. 0821 / AC / 2019 / PA Kdl.

Then, the Plaintiff named Slt bin Kr filed joint property (Gono-gini) against the Defendants named Spt bin Wky with his complaint letter dated June 19, 2019 registered at the Registrar of Kendal Religious Court No. 1279 / Pdt.G / 2019 / PA Kdl , dated June 19, 2019 by postulating as mentioned above.

Plaintiff named SIt binti Kr Defendant called Spt bin Wky came to the court that has been determined, then the judges give adequate explanations about mediation. Furthermore, the Plaintiffs named Slt binti Kr Defendant called Spt bin Wky reconciled through mediation by the mediator, and turns in the mediation process Plaintiffs named Slt binti Kr Defendant called Spt bin Wky has managed to resolve the issue peacefully by sending a letter of intent or peace letter signed by the Plaintiff named Slt binti Kr Defendant called Spt bin Wky that it is the whole property together (Gono-ginı) granted or awarded to 2 (two) children named HT and HTS.

In a subsequent trial, therefore the Plaintiff named Slt binti Kr Defendant called Spt bin Wky has successfully peacefully with their letters of intent or letters of peace are made and signed Tangai by Plaintiffs named Slt binti Kr Defendant called Spt bin Wky contents that the whole property together (Gono-gini) granted or awarded to 2 (two) children named HT and HTS, then by virtue of the peace agreement or letter of Judge (Judges) made Deed past peace keeping. In the Settlement Deed The Judge (Judges) decided not to be the Plaintiff named Slt binti Kr Defendant called Spt bin Wky obey the contents Akat Peace in accordance with the letter of the agreements made and signed by the Plaintiff named SIt binti Kr Defendant named the Wky bin Spt.

Because, letter or letter of the peace agreements made and signed by the Plaintiff named Tangai Slt binti Kr Defendant called Spt bin Wky not violate the boundaries of the law, religion and morality, and also does not conflict with Islamic law,

\subsection{Barriers and Solutions Implementation Of Grants Treasure Together Of Child Due Divorce}

As for barriers and solutions implementation grant joint property to the children of divorce are the First, When the father and mother are divorced do not agree or do not want to grant the joint property to his son or father and mother agreed but there are conditions that are difficult to be implemented then the child not eligible for the joint property of the father and mother so that should grant joint property can be implemented if the father and mother agree and want and do not have certain requirements that are difficult to be implemented. Secondly, if the child was given a grant of common property (Gono-gini) by the father and mother are still under age or immature or not yet reached the age of 21 years, then the property together (Gono-gini) granted by the parents to the child remain occupied or maintained or under the supervision of the parents of the child either by the father or by the mother. Then, after the child has grown or has reached the age of 21 years, the asset together (Gono-gini) are left entirely to the child, because the child has been able to keep the treasure and has been able to manage such property.

\section{Closing}

\subsection{Conclusion}

- Implementation Of Grants Treasure Together Of Child Due Divorce in Islamic Court 
Kendal is after the ruling Islamic Court Kendal regarding the grant of common property to children due to divorce and children who were given grants jointly owned by the parents of immature the joint property granted to her for the time being maintained or controlled by her father and mother, because minors have not been able to manage such property. However, if after the Court's decision regarding the grant Kendal Religion joint property to the children of divorce and child has grown so common property donated by the parents to the child directly controlled by the child because the child is able to regulate the treasure.

- Considerations Related Judge Kendal Religious Court decision in granting treasure Together Of Child Due Divorce can be done if the father and mother who have agreed to grant the divorce the common property to his son, accompanied by peace deed signed by both parents. However, if the father or mother does not agree on joint property donated to his son, or father and mother agreed but there is a requirement of the father or mother are difficult to implement the common property cannot be granted or given to their children.

- Obstacles and solutions implementation grant joint property to the children of divorce are When husband and wife divorced do not agree to grant joint property to his son or father and mother agreed but there are conditions that are difficult to be implemented then the child is not entitled to a joint property so it should grant joint property can be implemented if the father and mother agreed and have no specific requirement. If the children who were given a grant property shared by his parents still immature, the joint property granted to the father and son maintained or mother of his child. After her adult son, then the property along given entirely to his children, because the child has been able to maintain his property and was able to set up the treasure.

\subsection{Suggestion}

- Religious Courts Judges examine, decide and finalize their divorce case, especially in the case of property that is granted to a child, should have regard to the legal protection of a husband, wife, and son.

- Religious Court judges in deciding the case of common property grants to children of divorce should reflect a sense of justice, reflect a sense of legal certainty, and reflects the legal expediency.

\section{References}

[1] Act No. 1 of 1974 About Marriage

[2] Compilation of Islamic Law

[3] A copy of the Decision Kendal Religious Court, No. 1451 / Pdt.G / 2016 / PA Kdl

[4] A copy of the Decision Kendal Religious Court, No. 1279 / Pdt.G / 2016 / PA Kdl

[5] The jurisprudence of the Supreme Court decision No. 266 / K / AG / 2010

[6] Abdul Manan,2001, Problematika perceraian Karena Zina Dalam Proses Penyelesaian Perkara Di lingkungan Peradilan Agama, Mimbar Hukum, No. 52 Thn. XII, Jakarta: AlHikmah and Ditbinbapera Islam.

[7] Masri Singrimbun and Sofyan Efendi, 1995, Metode Penelitian Survai, Jakarta: LPJES

[8] Ronny Hanitijo Soemitro, 1998, Metodologi Penelitian Hukum dan Jurimetri, Jakarta: Ghalia Indonesia

[9] Abdul Kadir Muhammad, 1988, Perkembangan Hukum Keluarga Di beberapa Negara Eropa, Bandung: Publisher Aditya Bakti. 